\title{
CRIMSONpublishers
}

\author{
http://www.crimsonpublishers.com
}

\section{Secondary Metabolites from Algae for Nutraceutical Applications}

\author{
Ranga Rao A ${ }^{1 *}$, Vijaya Ramu $\mathbf{D}^{\mathbf{1}}$, Ravishankar GA ${ }^{\mathbf{2}}$ \\ ${ }^{1}$ Department of Biotechnology, Vignan`s Foundation for Science, Technology and Research University, India \\ ${ }^{2}$ Dr. C. D. Sagar Center for Life Sciences, Dayananda Sagar Institutions, India
}

*Corresponding author: Ranga Rao A, Department of Biotechnology, Vignan's Foundation for Science, Technology and Research University (VFSTRU), Guntur-522213, Andhra Pradesh, India

Submission: October 16, 2017; Published: November 13, 2017

\section{Editorial}

An increasing global concern on healthy foods is a major effort to drive the worldwide nutraceuticals market. Dietary supplements sector is receiving great importance in developed regions of the World. The global nutraceuticals market raised to $\$ 205.39$ billion in 2016 , and it is expected to reach $\$ 297$ billion by 2023 at a compound annual growth rate (CAGR) of $6.5 \%$ over 2018-2023. The current global start-ups concerning the demand for nutraceuticals need to focus research on exploration of robust secondary metabolites from microbial resources having high nutraceutical value for the future benefit of human beings. Microalgal metabolites are witnessing increasing demand in globally for their use in nutraceutical applications [1]. A few algal species namely Chlorella, Haematococcus, Dunaliella, and Spirulina offer a wide range of secondary metabolites for the development of healthier food products [2,3]. Even though, alga produces secondary metabolites such as alkaloids, flavonoids, glycosides, terpenoids, and phenazines [4]. In addition to secondary metabolites, algae contain proteins, carbohydrates, lipids, polysaccharides, polyols, and phycobiliproteins etc [5-8]. These secondary metabolites are numerously used in various health food sectors [9]. Secondary metabolites in algae have been enhanced by providing various stress conditions [10-12]. Secondary metabolites in microalgae have undergone detailed pharmacological evaluations [13]. Some of the studies have been performed by testing secondary metabolites against microorganisms and also by assessment of cytotoxicity against cell culture models [14]. Algal metabolites described in the literature, , still needs detailed analysis of their biological activities. Phytochemical investigations of algae have been evaluated only a few algal species; further work should be aimed to explore the chemistry and biological activities of lesser known species. Culturing micro algal species, and thus securing a reliable source of material for investigation, may be very useful in the future as the most potent source of biologically active compounds. Secondary metabolites from algae have an economic impact in various sectors such as food, feed, aquaculture, biomedicine, veterinary medicine, cosmetic industries and also health. An economic importance of microalgae, urgent need to improved techniques of isolation and characterization of bioactive compounds compared novel strategies for bio-prospection, for rapid screening of extracts and fractions for bioactivities. In addition, algae have the potential for the development of several biotechnological processes because of the expanding market for algal-based products without harming the marine ecosystem and also environment. Further improvements in the controlled cultivation, harvesting and conservation of algae will be required to permit the sustainable, large-scale production of algae and algal-derived products while avoiding further harm to the marine ecosystem and also environment. However, microalgae especially of marine species still remain to date largely unmapped and represent a unique opportunity to explore novel secondary metabolites in a cost-effective manner. Micro algalbased metabolites are known to bring a wide diversity of molecular targets and which enhance as nutraceutical potentials $[15,16]$.

\section{Acknowledgement}

The authors acknowledge Vignan`s Foundation for Science, Technology and Research University for providing financial support and research facility for this work.

\section{References}

1. Moreno-Garcia L, Adjalle K, Barnabe S, Raghavan GSV (2017) Microalgae biomass production for a bio refinery system: Recent advances and the way towards sustainability. Renewable and Sustainable Energy Reviews 76: 493-506.

2. Gouveia L, Marques AE, Sousa JM, Moura P, Bandarra NM, et al. (2008) Microalgae-source of natural bioactive molecules as functional ingredients. Food Science and Technology Bulletin Functional Foods $7(2): 21-37$.

3. Guedes AC, Amaro HM, Malcata FX (2011) Microalgae as sources of carotenoids. Mar Drugs 9(4): 625-644.

4. Alassali A, Cybulska I, Alkhori A, Przemyslaw Brudecki G, M Thomsen, et al. (2016) Methods for upstream extraction and chemical characterization of secondary metabolites from algae biomass-a mini review. Adv Tech Biol Med 4(1): 1-16.

5. Borowitzka MA (2013) High-value products from microalgae their 
development and commercialization. Journal of Applied Phycology 25(3): 743-756.

6. Koller M, Muhr A, Braunegg G (2014) Microalgae as versatile cellular factories for valued products. Algal Research 6(A): 52-63.

7. Pulz O, Gross W (2004) Valuable products from biotechnology of algae. Appl Microbiol Biotechnol 65(6): 635-648.

8. Spolaore P, Joannis-Cassan C, Duran E, Isambert A (2006) Commercial applications of microalgae. J Biosci Bioeng 101(2): 87-96.

9. Wells ML, Potin P, Craigie JS, Raven JA, Merchant SS, et al. (2017) Algae as nutritional and functional food sources: revisiting our understanding. Journal of Applied Phycology 29(2): 949-982.

10. Ranga Rao A, Deepika G, Ravishankar GA, Sarada R, Narashimarao BPR, et al. (2017) Botryococcusas an alternative source of carotenoids and its possible applications-an overview. Crit Rev Biotechnol 1-18.

11. Ranga Rao A, Sarada R, Ravishankar GA, Phang SM (2016) Industrial production of micro algal cell-mass and bioactive constituents from green micro alga-Botryococcusbraunii. In: Liu J, Sun Z, Henri G (Eds.), Recent Advances in Micro algal Biotechnology. OMICS Group Incorporation, 731 Gull Ave, Foster City, CA 94404, USA, pp. 103-126.
12. Sarada R, Ranga Rao A, Sandesh BK, Dayananda C, Anila N, et al. (2012b) Influence of different culture conditions on yield of biomass and value added products in microalgae. Dyn Biochem Process Biotechnol Mol Biol 6(2): 77-85.

13. De Morais MG, Vaz BDS, De Morais EG, Costa JA (2015) Biologically active metabolites synthesized by microalgae. Biomed Res Int 835761.

14. Hafsa MB, Ismail MB, Garrab M, Aly R, Gagnon J, et al. (2017) Antimicrobial, antioxidant, cytotoxic and anticholinesterase activities of water-soluble polysaccharides extracted from microalgae Isochrysis galbana and Nannochloropsisoculata. Journal of Serbian Chemical Society 82(5): 509-522.

15. Borowitzka MA (1995) Microalgae as sources of pharmaceuticals and other biologically active compounds. Journal of Applied Phycology 7(1): 3-15.

16. Ranga Rao A, Sarada R, Ravishankar GA (2010) Enhancement of carotenoids in green alga-Botryococcusbraunii in various autotrophic media under stress conditions. Int J Biomed Pharmaceuti Sci 4(2): 8792. 